Canadian University Music Review

Revue de musique des universités canadiennes

\title{
Tracing the Chiasmus: A Response to William Renwick
}

\section{Adam Krims}

Volume 20, numéro 2, 2000

URI : https://id.erudit.org/iderudit/1014457ar

DOI : https://doi.org/10.7202/1014457ar

Aller au sommaire du numéro

\section{Éditeur(s)}

Canadian University Music Society / Société de musique des universités canadiennes

\section{ISSN}

0710-0353 (imprimé)

2291-2436 (numérique)

Découvrir la revue

\section{Citer cet article}

Krims, A. (2000). Tracing the Chiasmus: A Response to William Renwick. Canadian University Music Review / Revue de musique des universités canadiennes, 20(2), 42-44. https://doi.org/10.7202/1014457ar
Résumé de l'article

This response addresses those of Renwick's critiques that can be addressed briefly: the status of a Schenker analysis not done by Schenker, whether or not the original article was a "deconstruction," and whether Julia Kristeva can be assimilated satisfactorily to structural linguistics. More fundamentally, the response proposes that, despite his stated ambitions, Renwick, in fact, provides a deeply heterogeneous Schenker; and finally, that Renwick's claim for music theory's current practices rests on a conflation of productivity, as I describe it, with electicism.
All Rights Reserved (C Canadian University Music Society / Société de musique des universités canadiennes, 2000
Ce document est protégé par la loi sur le droit d'auteur. L'utilisation des services d'Érudit (y compris la reproduction) est assujettie à sa politique d'utilisation que vous pouvez consulter en ligne.

https://apropos.erudit.org/fr/usagers/politique-dutilisation/ 


\section{TRACING THE CHIASMUS: A RESPONSE TO WILLIAM RENWICK}

\section{Adam Krims}

William Renwick's response to my article is informative from all sorts of angles, some of which invite a much more detailed account than is reasonable here. Instead, I will clarify three localized points and then draw out a remarkable chiasmus that is, I think, most engaging. First to the clarifications:

(1) Renwick is correct that my Schenker analysis (and also my Schoenbergian interpretation, though interestingly he does not extend to that point) represents my own view, and of course, not Schenker's. And in fact, the article carefully maintains that delineation: the narrative constructs a Schenkerian interpretation based on Free Composition, leading to the (I hope, now familiar) problem of first-order neighbours (about which more will be said shortly). Since Schenker no longer is analyzing music-one is perhaps reminded of that tasteless riddle about what Beethoven is now doing-he only exists in such encounters of analysts/readers with his texts, and that is precisely the scenario of the article. Thus, while Renwick is certainly correct that the graph is mine and not Schenker's, the point is, as a practical matter, trivial; in the meantime, it is worth observing that in his own graph, he replays the same encounter with the problematic of first-order neighbours, using his own preferred criteria of form to proffer a solution, so to speak. Productivity, such as I describe it, is precisely the encounter of the analyst with music-theoretical texts, which is why the article narrates it as such; no ghosts of Schenker are invoked, nor, I assume he and I would both agree, should they be invoked.

(2) While Renwick is probably correct that my ideas could, with some tinkering, be assimilated to some version of deconstruction, I would caution against such a strategy (for reasons better spelled out in my article "Disciplining Deconstruction (for Music Analysis)"; 1 as things stand, contrary to his assumption, my article in no way deconstructs Schenker, but rather proposes the very different notion of productivity as a way framing music-analytical theories.

(3) Speaking of encounters with texts, it is worth pointing out that although Renwick is correct that Kristeva discusses both "immediate constituent" and "generative grammar" in the work to which he refers, neither term is central to her problematic, except perhaps as ground to figure. Furthermore, the work to which he refers is considerably later than the work to which I refer; thus, its relevance, even if those two terms were more central, is at best in doubt. Rather,

${ }^{1}$ Adam Krims, "Disciplining Deconstruction (for Music Analysis)," Nineteenth-Century Music 21, no. 3 (1998): 297-332. 
true to the spirit of early post-structuralist linguistics in which she constitutes such an outstanding figure, she is interested, in the work to which I refer, precisely in the disruptive elements of language (with some heavy psychoanalytic apparatus that I purposefully leave aside). Overall, any connection of her work with, for example, generative grammar (with all due respect to Chomsky, and to Lerdahl and Jackendoff) will be oppositional rather than complementary. Thus, any attempt to assimilate her project to the latter is, it seems to me, intellectually fragile.

Now, on to the chiasmus. It is clear, I would think, to readers that William Renwick and I agree substantially on some points and disagree on others. Oddly, though, we agree on matters he seems to see as items of disagreement, and we disagree in places where he seems to believe we agree. Although one may begin in either leg of this presumably inadvertant chiasmus, let us set out with the former.

Renwick takes exception to my qualifying Schenker's models of voice-leading and form as "fundamentally heterogeneous," shortly after identifying him as precisely so. As both Renwick and I recognize, Schenker is unambiguous in saying that voice-leading takes a determinative (and generative) priority to form: such is, in fact, a point that Schenker stresses in Free Composition. ${ }^{2}$ Yet, as Renwick quite convincingly demonstrates, the only way to make sense of Schenker's (graphic and implicit) hierarchy of upper neighbours to Urlinie tones in Free Composition is to conclude that they are distinguished by formal function. Renwick follows Schenker in his own analysis of the Impromptu, offering a graphing and explication that explicitly rely on formally prominent pitch features. The results are perfectly satisfactory. My own preference, by contrast, is to follow Schenker's word about the priority of voice-leading, and in a more technically-focused context, I might wish to argue for the desirability of the resulting counterpoint with formal function. Of course, neither my nor Renwick's procedures contributes much toward achieving the "unity" of prose and graph that he desires-such would require either a different primary text or some massive acts of repression. What is more remarkable, though, is that his own version of Schenker is, in fact, a good deal more heterogeneous than mine (and follows Schenker's graphing practice in being so). All the more striking, then, is Renwick's desire to deny Schenker's heterogeneity, especially since it is the latter which he stresses as an analytical solution to the Impromptu. He and I do agree in relying on that heterogeneity, though I am, at this point, alone in naming it as such.

The other leg of the chiasmatic figure finds us actually diverging where Renwick sees agreement, and that is on the issue of whether the productivity of which I speak actually already exists, in a widespread fashion, in the current professional practice of music theory. Behind Renwick's position here is a conflation of productivity, as I describe it, with simple eclecticism. He is no doubt correct that many scholars with Schenker analysis as a principal methodology avail themselves of other theoretical approaches, including but not limited to

\footnotetext{
${ }^{2}$ See paragraphs $301-312$ and 316,324
} 
Schoenberg's regions (and Barbara Hampson's M.A. thesis that he cites could well be a valuable contribution to that). But that eclecticism, fortuitous though its results often are, is nevertheless a vast theoretical distance from the intrinsic instability I propose to music-analytical systems and the consequent dependence on formed theories with conflicting principles. A considerable distance thus separates productivity from the ad hoc eclecticism that Renwick justifiably celebrates; we are widely separated, thus, where he sees a point of convergence.

The most engaging aspect of the chiasmus is not the figure itself, but rather the ultimately social aspects of our respective stances, aspects that, in retrospect, could better have been drawn out in my original article. At stake is how music theory works qua theory, and the workings of aesthetic ideology and musical autonomy. That is the world onto which our dialogue opens, and Renwick's incisive and engaging remarks form an important part of that project. I thank him for his important contribution, and the Canadian University Music Review for hosting our exchange.

\begin{abstract}
This response addresses those of Renwick's critiques that can be addressed briefly: the status of a Schenker analysis not done by Schenker, whether or not the original article was a "deconstruction," and whether Julia Kristeva can be assimilated satisfactorily to structural linguistics. More fundamentally, the response proposes that, despite his stated ambitions, Renwick, in fact, provides a deeply heterogeneous Schenker; and finally, that Renwick's claim for music theory's current practices rests on a conflation of productivity, as I describe it, with electicism.
\end{abstract}

